UDC 330

\title{
MODELING OF CRISIS PHENOMENA IN REGIONAL STOCK MARKETS BY WAVELET-ENTROPY METHOD
}

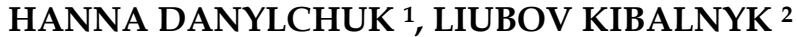 \\ 1 The Bohdan Khmelnytsky National University, Cherkasy, Ukraine \\ ORDID: https://orcid.org/0000-0002-9909-2165 \\ e-mail: abdanilchuk@gmail.com \\ 2 The Bohdan Khmelnytsky National University, Cherkasy, Ukraine \\ ORDID: https://orcid.org/0000-0001-7659-5627 \\ e-mail: liubovkibalnyk@gmail.com
}

\begin{abstract}
The article reflects the results of a study on modelling regional stock markets using wavelet entropy. Particular attention is paid to periods of crises as special states of markets. Countries with the developed economies were selected for the study, namely, the United States, United Kingdom, Germany, France, China, Japan and Hong Kong. The values of stock indices of regional stock markets were used as a statistical base. The research period is from 2015 to 2021. The aim of the article is to monitor the current state of markets and to demonstrate the possibilities of using the wavelet entropy index as a precursor of crisis phenomena.

The wavelet entropy method was used. All calculations were performed in the Matlab environment - a system for modeling nonlinear dynamical systems.

The results of the study demonstrate the absence of crisis phenomena in these markets as of April 2021. It is shown that the use of wavelet entropy as a precursor indicator is reasonable. In particular, the reaction of stock markets to such crisis situations as the COVID-19 pandemic as well as other socio-political events is shown.

Based on the results of calculations, conclusions are made about the current state of stock markets of the studied countries. All stock market participants, investors, and relevant ministries to develop effective strategies can use the results obtained, as well as the method in general.
\end{abstract}

Keywords: Economic crisis; modeling; regional stock markets; wavelet entropy, precursor.

\section{DOI: 10.31891/mdes/2021-1-2}

\section{INTRODUCTION}

Recently, the world has been absorbed by crises, crisis phenomena, shocks, crashes, which are different in nature, manifestations, and power. The processes of globalization taking place in the world have both positive and negative consequences. From the point of view of the spread of crisis phenomena, globalization processes, in our opinion, are the high-speed tunnel that allows crises to spread without obstacles and to "infect" the economies of the world. The study of the course and consequences of crisis phenomena, as well as the study of emergence moment of the crisis, deserve the same special attention.

Thus, important issues about the general points of misunderstanding the nature of crises and the imperfections of the models used to study crises are revealed by Colander et al. (2009). The analysis of scientific achievements in research and modelling of crises allow distinguishes three generations of models of currency crises (Burnside et al., 2007). Against the background of economists' failures in predicting the crisis of 2008-2009, Wieland and Wolters (2012) offer a comparative approach to the analysis of macroeconomic policy. For this purpose, they have developed a database of macroeconomic models, which allows choosing a method of modeling according to the situation. According to the authors, this will allow to obtain an adequate model and provide certain recommendations for decision-making. Basu (2009) analyses the financial crisis of 2007-2008 starting as a local problem in the US mortgage financing market and growing into a global recession after some time, and offers a model combining microeconomic and macroeconomic arguments. Strutt and Walmsley (2011) study the effects of the global financial crisis on China using a dynamic equilibrium model. To this purpose, scenarios have been developed, and the impact of the exit time from the crisis in terms of consequences for the world economy is studied. The European debt crisis is investigated by Bocola et al. (2019). A standard quantitative model of state default is used to study the debt crisis on the example of the European countries (Portugal, Spain, and Italy). To improve the performance of the model and the reliability of the results, the expansion of the model is proposed using introducing real variables. Armansyah and Effendi (2017) use Multivariate Adaptive Regression Spline to build the model of the financial crisis in Indonesia. According to the study results, conclusions were made about the possibility of obtaining information about the factors based on this model that can lead to a crisis. Gertler et al. (2017) study recent financial crises. Particular attention is paid to banking panic and the circumstances that can make a country's economy vulnerable to such panic. For purpose, a macroeconomic model the bank sector is used; however, the problem of the role of macroprudential policy remains unsolved. Mariano et al. (2000) determine the need and feasibility of forecasting financial and economic 
crises. To prevent crises early, the Markov chain method is proposed. The proposed method was tested on the example of Turkey. Harvey (2010) builds a model considering both the unique characteristics of crises and the common moments occurring at the emergence and the course of crisis phenomena. A schematic method, which allows tracking processes over time, identifying the interrelated factors, is used. Chen et al. (2020) use a combination of the network technologies and spatial econometric model to model the impact of crises on the sectors the real economy and to identify the effects of spread (infection). It is necessary to allocate several scientific articles focusing the modeling of financial markets and identification of crisis periods with the use of economic and other interdisciplinary methods. These articles prove the effectiveness of entropy methods, network models, the Heisenberg uncertainty principle, scale-dependent Lyapunov indicators and other approaches for detecting and predicting crisis phenomena (See, e.g., Soloviev and Saptsin, 2011; Soloviev and Belinskij, 2018; Soloviev et al., 2019; Danylchuk et al., 2016; Danylchuk et al., 2019; Danylchuk et al., 2020).

This paper proposes the use of interdisciplinary approach of wavelet entropy to model financial markets, their special conditions and pre-forecasting analysis.

\section{MATERIALS AND METHODS}

The daily values of indices of regional stock markets of the countries (Yahoo Finance, 2021; InvestFunds, 2021) that have a highly developed economy. The list of the countries includes the United States, United Kingdom, Germany, France, China, Japan and Hong Kong. The data involve the period from January 1, 2015 to April 4, 2021.

Wavelet Entropy

The entropy of the wavelet transform provides a two-dimensional scan the time series. This allows to simultaneously analyze signals in two spaces - physical and temporal. The essence of the method of wavelet analysis is to introduce the appropriate basis and characteristics of the time series using the distribution of amplitudes in the introduced basis. There are two types of wavelet transform - continuous and discrete. Continuous Wavelet Transform (CWT) is used to study functions because the toolkit allows decomposing the function into elementary components. A representation of the time series with values in the form of coefficients in the sequence of wavelets can be received with the help of Discrete Wavelet Transform (DWT). The resulting sequence provides information about the series and local energy of its components at different scales. This type of wavelet transform is better suited for the study of economic time series.

To describe the basics of wavelet entropy, we turn to Zunino et al. (2006); Perez et al. (2005).

Let there be a time series, elements of which are presented on a uniform grid sampling time (frequency). The use of a set of scales allows to get such a wavelet transform:

$$
X(t)=\sum_{j=1}^{N} \sum_{k} C_{j}(k) \psi_{j, k}(t)=\sum_{j=1}^{N} r_{j}(t),
$$

where $r_{j}(t)$ - a value that contains information about the $\mathrm{X}$ series respectively at frequencies $2^{j-1} \omega_{s} \leq\left|\omega_{s}\right| \leq 2^{j} \omega_{s}, \psi$ - the mother wavelet, which is the basis of the wavelet transformation. Spectrum coefficients (wavelet coefficients) are defined as $C_{j}(k)=\left\langle S, \psi_{j, k}\right\rangle$, with their help, the energy at each scale $j=1, \ldots, N$ is submitted in the form of energy of the series elements. The wavelet energy of the spectrum is defined as the sum of the energies of each level:

$$
E_{\text {tot }}=\|X\|^{2}=\sum_{j=1}^{N} \sum_{k}\left|C_{j}(k)\right|^{2}=\sum_{j=1}^{N} E_{j} .
$$

Wavelet entropy based on wavelet transform is a quantitative measure of the ordered signal and is calculated by the formula:

$$
W E n=-\sum_{j=1}^{N} p_{j} \ln \left(p_{j}\right),
$$

where $p_{j}=\frac{E_{j}}{E_{t o t}}$ - relative wavelet energy, by which the distribution of wavelet energy is determined according to decomposition levels. A value of $p_{j}$, taken at different scales, form the energy probability distribution:

$$
\sum_{j=1}^{n} p_{j}=1
$$


Distribution $\left\{p_{j}\right\}$ can be considered as time-scale density and used as a tool to determine the characteristics of the series in time and frequency spaces.

Shannon's entropy is a measure of the information contained in distribution is a criterion for analyzing and comparing the probability distribution.

To determine the normalized total wavelet entropy, the following formula is proposed:

$$
E_{W T}=\frac{-\sum_{j=1}^{N} p_{j} \ln \left(p_{j}\right)}{X_{\max }}
$$

where $X_{\max }=\ln N$ - normalized constant. NTWE can be used as a measure of the degree of regularity (chaos) of the time series and provide information about the hidden dynamic processes occurring in the series.

The wavelet transform is automatically characterized by a moving frequency-time window. Procedurally, it is described as follows: windows of a certain length $L$ are chosen, while they do not overlap. Intervals $i$ are formed $i=1, \ldots, N_{T}$, where $N_{T}=\frac{M}{L}$. The corresponding values of the time series of each interval are compared with the central point of the window. Therefore, at least one wavelet coefficient on each scale will be at the shortest window length. The moving window highlights both low- and highfrequency signal characteristics equally well, being an advantage of this method.

Wavelet energy at scale $j$ for a time window is calculated by the formula:

$$
E_{j}^{(i)}=\sum_{k=(i-1) \cdot L+1}^{i \cdot L}\left|C_{j}(k)\right|^{2}, i=1, \ldots, N_{T}
$$

The total energy in this time window is equal to

$$
E_{\text {tot }}^{(i)}=\sum_{j=-N}^{-1} E_{j}^{(i)}
$$

The relative and normalized wavelet entropy to reflect the changes occurring over time is calculated by the following formulas:

$$
p_{j}^{(i)}=\frac{E_{j}^{(i)}}{E_{t o t}^{(i)}}, E_{W T}^{(i)}=-\sum_{j=-N}^{-1} p_{j}^{(i)} \cdot \frac{\ln p_{j}^{(i)}}{X_{\max }}
$$

Quian Quiroga et al. (1999) obtain the indicators of wavelet entropy - scale and point entropy based on the energy of wavelet coefficients. These types of indicators are based on the approach to data processing using Shannon's formula: scale processing is used for scale entropy, time processing - for point one. coefficients

When calculating both indicators of wavelet entropy, there is the energy field of wavelet $E_{i j}=C_{i j}^{2}$, which is normalized by the standard deviation of the original time series $\tilde{E}_{i j}=\frac{E_{i j}}{\sigma_{t}}$.

The approach to further calculations differs depending on the type of entropy being calculated.

The formula for calculating the scale entropy is:

$$
E_{W S}=-\sum_{i}\left(\left(\sum_{j} p_{i j}\right) \cdot \frac{\log _{2} \sum_{j} p_{i j}}{\log _{2} N}\right)
$$

where $p_{i j}=\frac{\tilde{E}_{i j}}{\tilde{E}_{t o t}}-$ density distribution of entropy probability, $E_{t o t}=\sum_{i} \sum_{j} \tilde{E}_{i j} ; \log _{2} N$ - normalizing factor (constant), $N$ - the number of time series elements.

To calculate the point entropy, the sums of energies on each scale is determined $\tilde{E}_{i}=\sum_{i} \tilde{E}_{i j}$ and the density distribution of energy probability is found by dividing energies of wavelet coefficients by the total energy of the corresponding scale $p_{i j}=\frac{\tilde{E}_{i j}}{\tilde{E}_{i}}$. The value of entropy at each point is found according to Shannon's formula: 


$$
E_{W P}=-\sum_{i}\left(\left(\sum_{j} p_{i j}\right) \cdot \frac{\log _{2} \sum_{j} p_{i j}}{\log _{2} N}\right)
$$

\section{RESULTS AND DISCUSSION}

The calculations were performed in the Matlab environment with the following parameters: window width is 750 points; step is 5 points. Fig. 1-3 show the results of measurements. In the left part of the figures, some crisis periods are highlighted by multi-colored ellipses. Through empirical research, it has been established that the indicators of wavelet entropy in the pre-crisis and the actual crisis period form three increasing waves. The pre-forecast element is manifested when the entropy values of the third wave exceed the maximum value of the second wave. When the third wave reaches its maximum, it corresponds to the moment of the actual crisis in the system. The values of entropy, the interval of the preforecast period for each system are different. The analysis of Fig.1 shows similar processes occurring in the markets of the US, France, and Germany. The American DJI market was not chosen by chance among all US markets; it is the best for comparison with European indices. Fig.1(a) shows the formation of three waves in a neighborhood of 1000 (corresponds to 2019) and in a neighborhood of 1300 (corresponds to 2020). For the USA, these periods are associated with the Trump administration. Thus, in 2019, a decision was made to normalize the country's monetary policy (i.e., in fact, the decision to turn off the money printing machine). This did not add to the popularity of $\mathrm{D}$. Trump, and his ratings at the time were the lowest among the last 13 presidents. In 2020, tensions between the United States and China increased. Although this state of affairs was almost always noted, the tension in relations reached its peak during the Trump administration. In the same year, 2020, the world was shocked by the rapid spread of coronavirus infection SARS-CoV-2. The COVID-19 pandemic has hit the world economy hard and made radical adjustments to human life. All current events, political, social, and economic ones, are reflected in the values of market indices. The use of wavelet entropy allows one seeing the hidden information. Thus, the energy field of wavelet coefficients demonstrates certain disturbances on a small scale that is the evidence of internal processes occurring in the market or the country as a whole (for example, Fig. 1 (a) right). For the markets of France (Fig. 1 (b)) and Germany (Fig. 1 (c)), the characteristic features of the last period are the formation of several triads of waves that is evidence of a systemic crisis. For European countries, it is associated with several reasons: the UK withdrawal from the European Union, political unrest in France, the pandemic. For the German market (Fig. 1 (c)), we can note three crises occurring one after another.

It should be noted that for the UK market (Fig.2(a)), the withdrawal of the country from the European Union also affected the economic situation. This is confirmed by the formation of three waves in a neighborhood of 800 . The effects of the pandemic for the UK also caused a crisis situation (in a neighborhood of 1300). It is better to measure the broad market of the United States by the S\&P500 index (see Figure 2 (b)). According to the indicators of wavelet entropy for this market, we note the reaction to global and domestic events mentioned above.

We note certain features in the behavior of the entropy index in the study of Asian markets (Fig,3). Thus, in the Chinese market (Fig,3(a)), small disturbances occur in a neighborhood of 1000 (corresponds to 2019). The end of 2019 is the period of the beginning of the global pandemic in China. However, the behavior of the entropy index indicates the relative state of calm in the stock market. This reflects the efforts of the country and its leadership to resolve the situation in all areas and activities. The current period for China is also characterized by a fairly stable state.
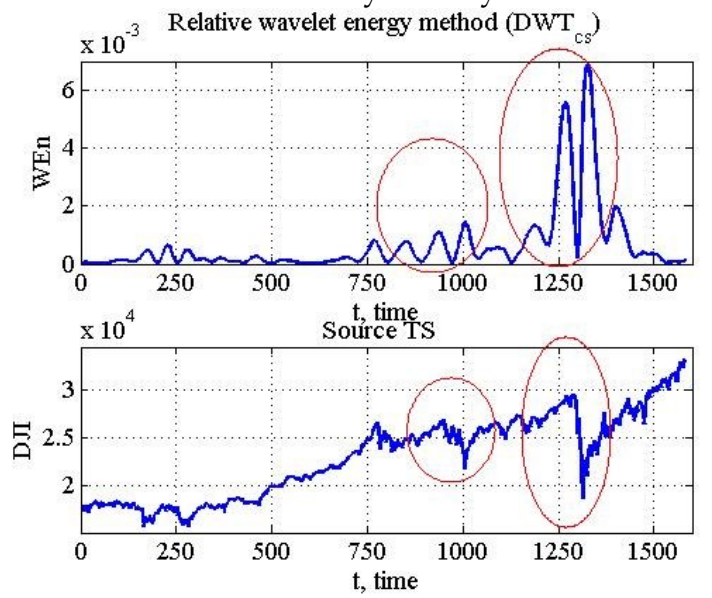

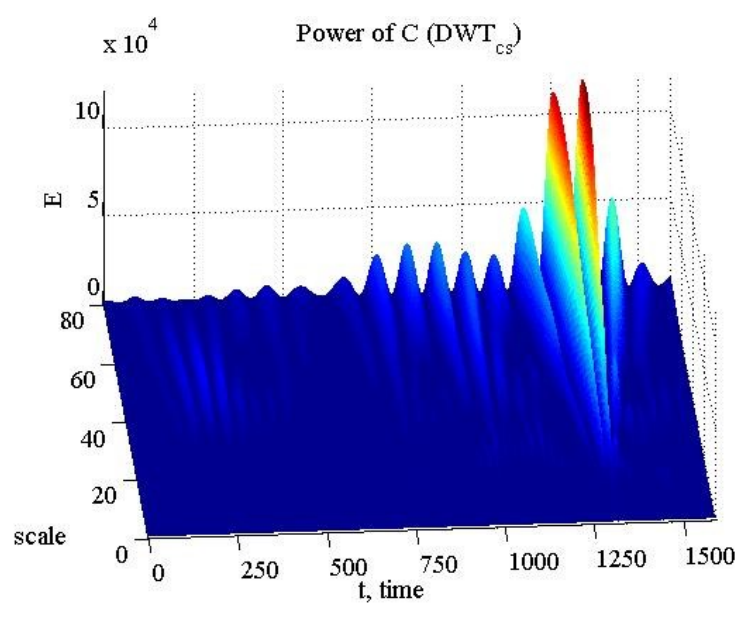




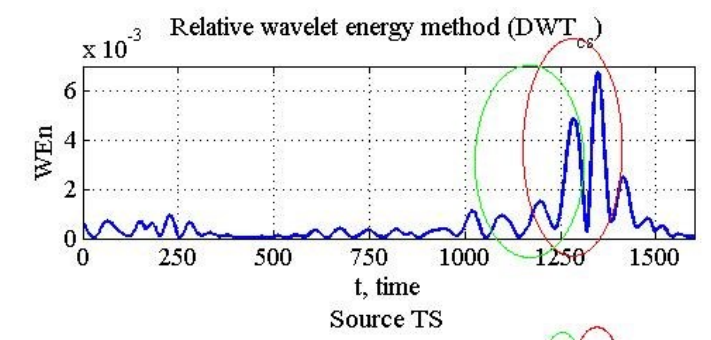

a)

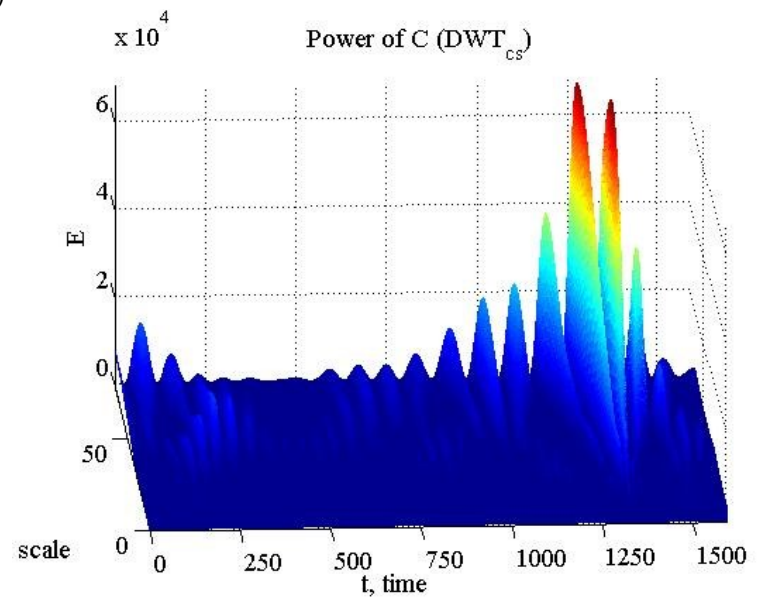

b)
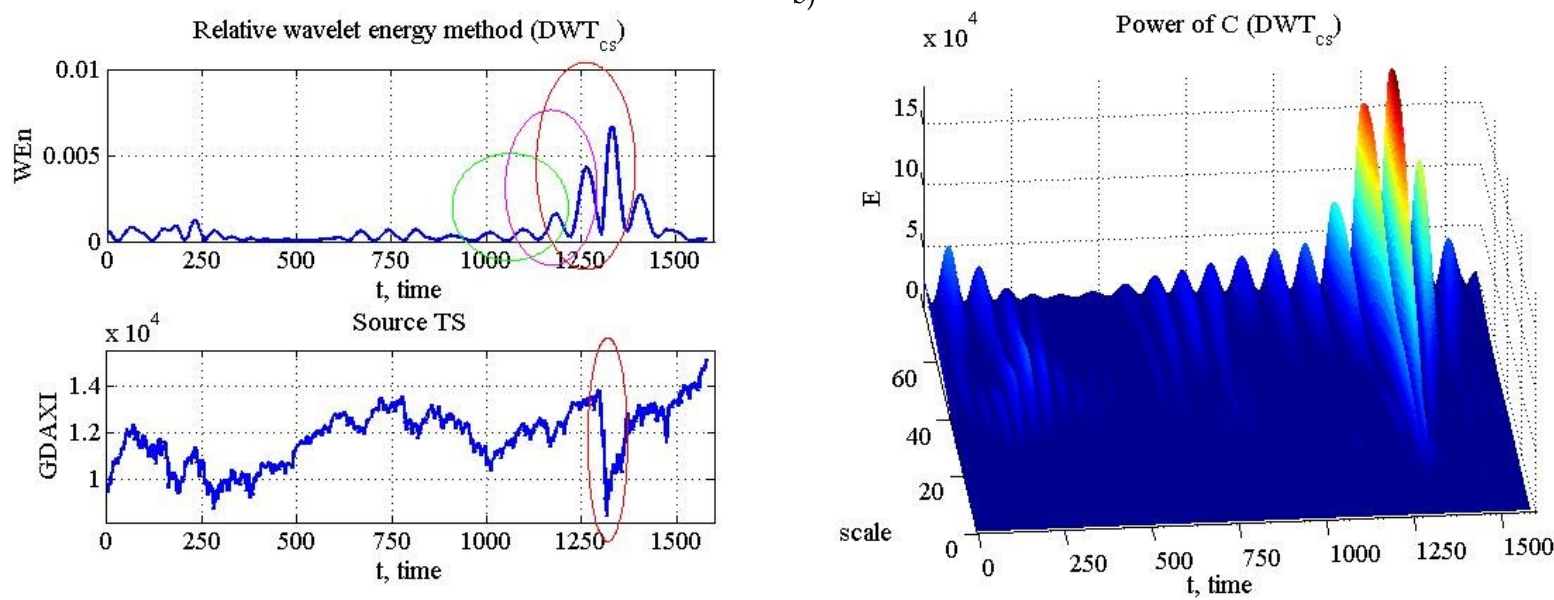

c)

Figure 1: Wavelet entropy and time series dynamics (left) and wavelet coefficient energy (right) for stock markets of: (a) the United States, (b) France, (c) Germany
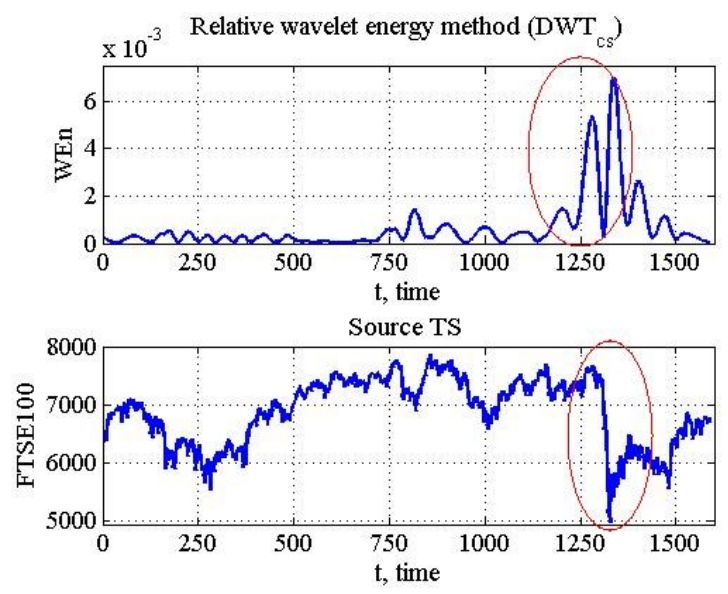

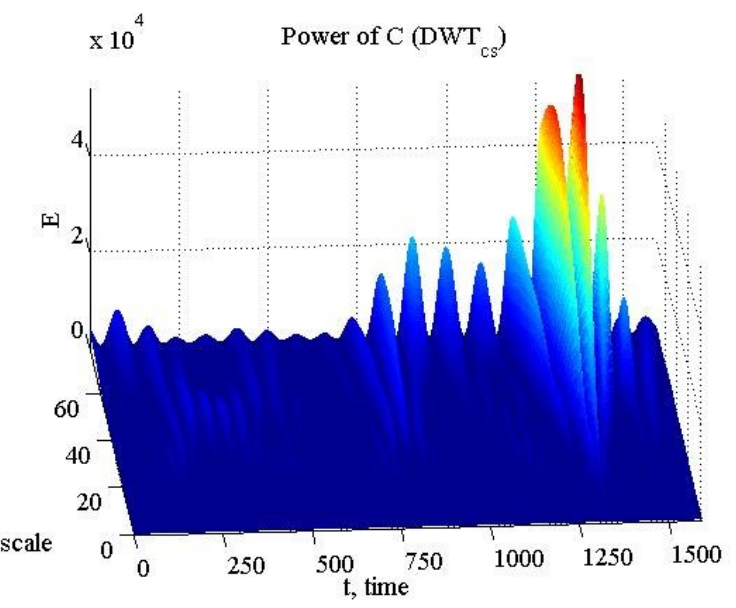

a) 

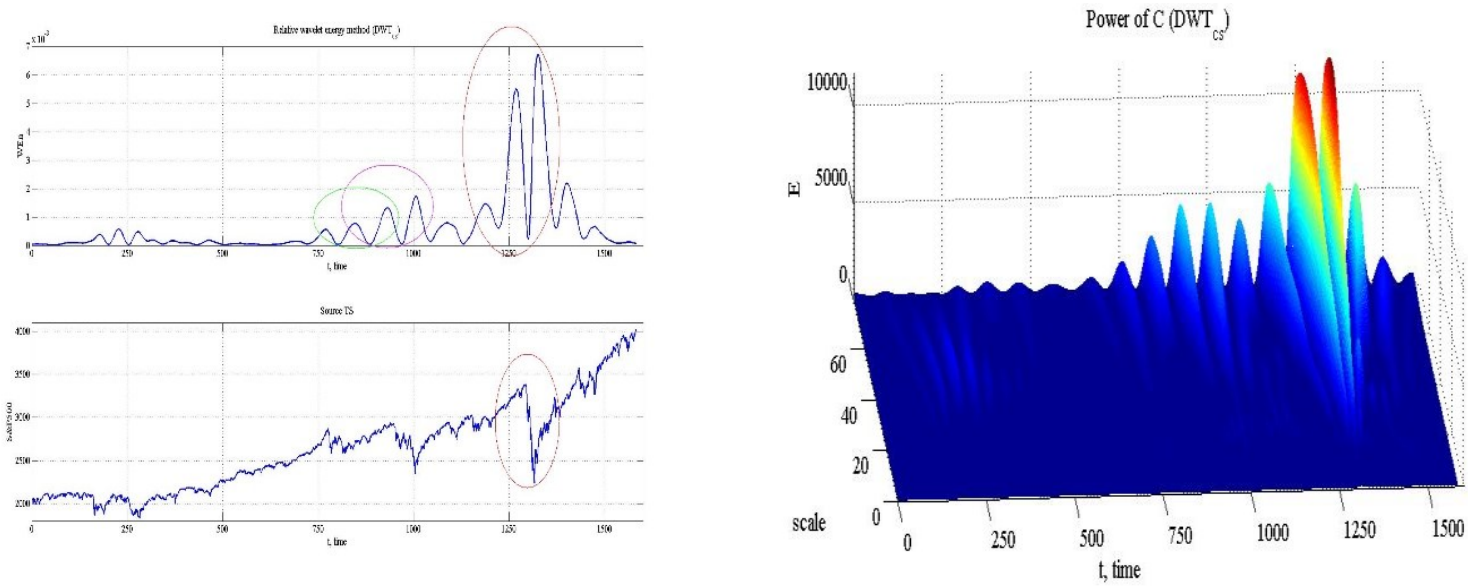

b)

Figire 2: Wavelet entropy and time series dynamics (left) and wavelet coefficient energy (right) for the stock markets of: (a) the United Kingdom, (b) the United States

The turbulent course of events is observed in the Hong Kong market (Fig. 2 (b)). The market reaction to the pandemic is unquestionable; we can see the formation of three rising waves in a neighborhood of 1000. Small-scale disturbances occur at a small scale throughout the study period (see Fig. 2 (b) right), which may be evidence, e.g., of internal speculative actions in the market.

For the Japanese market, we observe the formation of three waves in a neighborhood of 750 (corresponding to 2018) and a neighborhood of 1250 (corresponding to 2020). Regarding the pre-forecasting capabilities of the wavelet entropy, it should be noted that for almost all studied stock markets, a gap of about 50 points (up to 2 months) is formed, which is a signal of crisis onset.
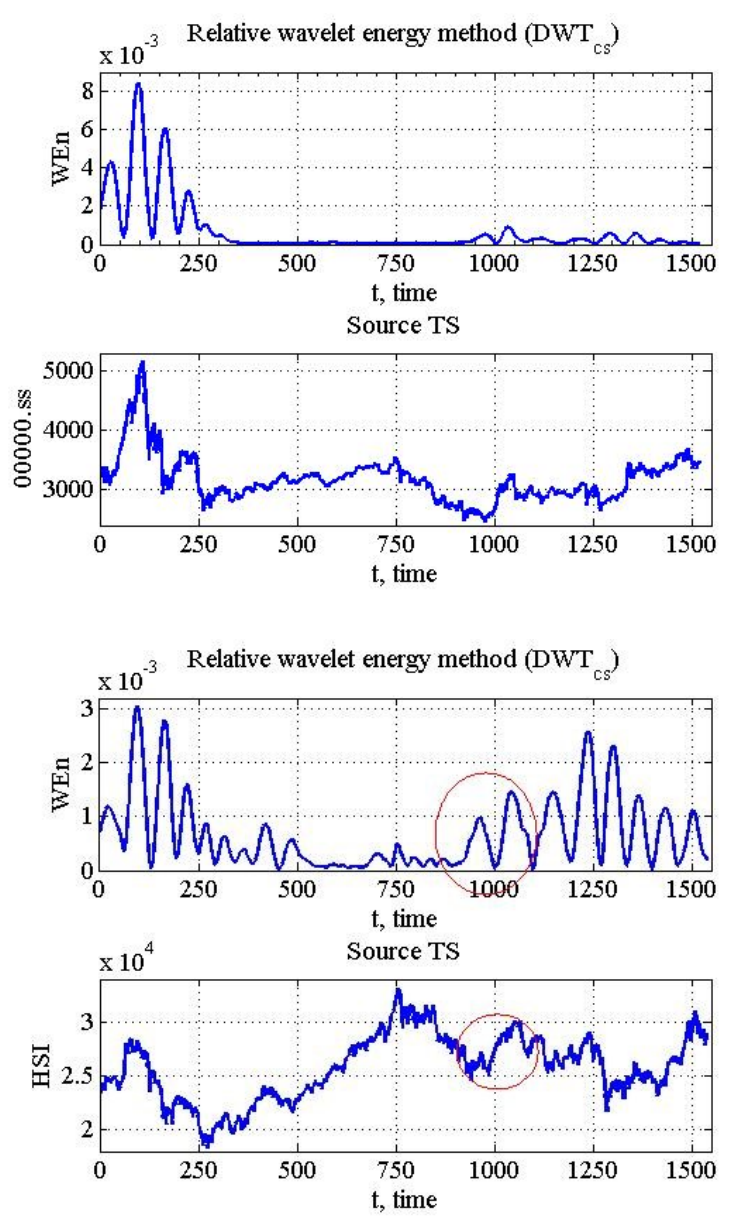

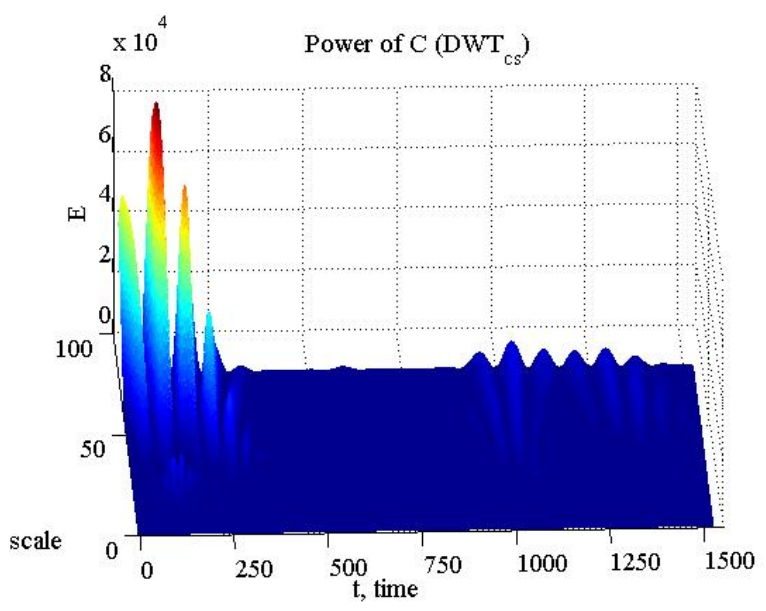

a)

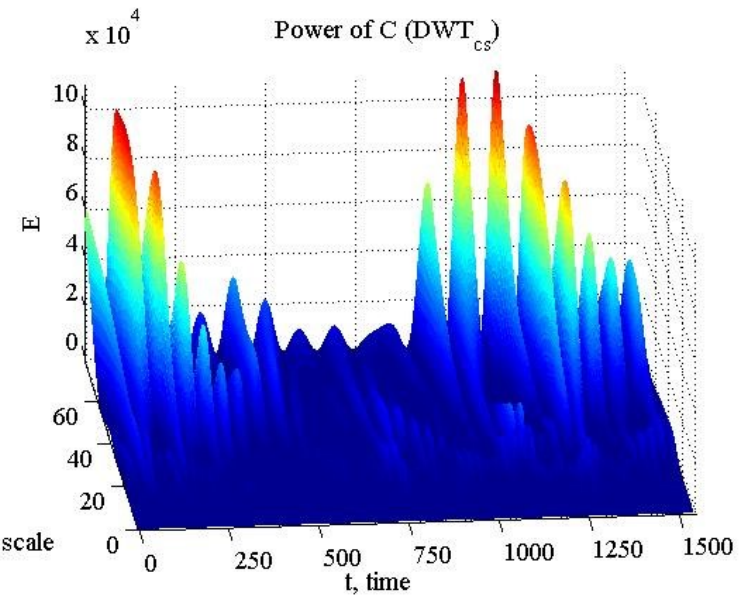

b) 

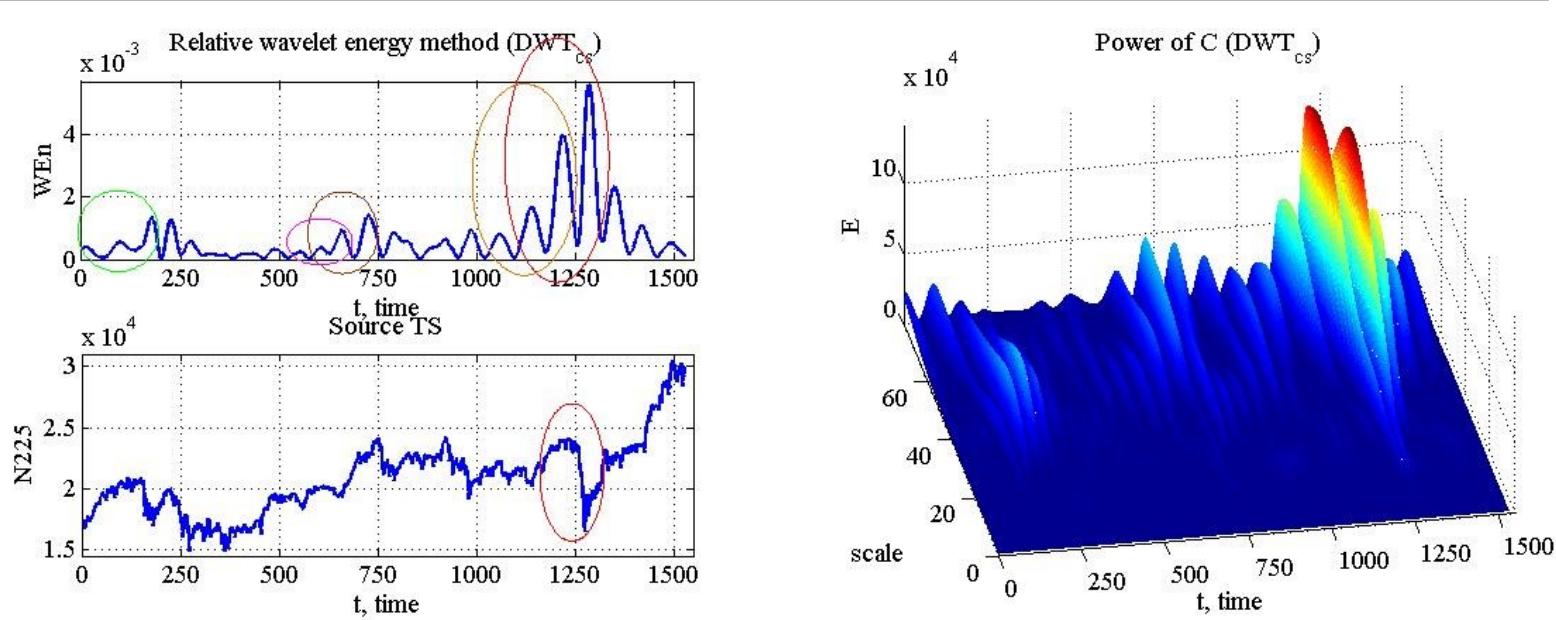

c)

Figure 3: Wavelet entropy and time series dynamics (left) and wavelet coefficient energy (right) for the stock markets of: (a) China, (b) Hong Kong, (c) Japan

Thus, based on the study of regional stock markets using wavelet entropy indicators, we can conclude that the current state of the markets is quite stable. All markets responded to the crises caused by socio-political events and the COVID-19 pandemic. The wavelet entropy index is an effective indicator and a precursor of crisis phenomena.

\section{CONCLUSION}

The paper studies the regional stock markets of the countries with highly developed economies. The study uses real data - stock market indices. Special states in these markets are modeled using the interdisciplinary method of wavelet entropy. The use of this method allows to find the hidden characteristics of time series at different scales and to obtain pre-forecasting analysis of time series. In particular, the reaction of all markets to the spread of coronavirus infection was noted. However, both the beginning and the course of the crisis are different for the countries studied. It is shown that the wavelet entropy index serves as an indicator-precursor of crisis phenomena. The indicator felt the formation of the crisis approximately 50 days before the actual crisis. The current period of the studied markets is marked by a stable state. The obtained research results can be used by both scientists and practicing economists. The wavelet entropy method can be used to monitor and model regional stock markets to identify and predict crisis phenomena.

\section{CONFLICT OF INTEREST}

The authors declare no potential conflict of interest regarding the publication of this work. In addition, the ethical issues including plagiarism, informed consent, misconduct, data fabrication and, or falsification, double publication and, or submission, and redundancy have been completely witnessed by the authors.

ABBREVIATIONS

\begin{tabular}{|l|l|}
\hline$C W T$ & Continuous Wavelet Transform \\
\hline$D W T$ & Discrete Wavelet Transform \\
\hline NTWE & Normalized Total Wavelet Entropy \\
\hline$W E n$ & Wavelet entropy \\
\hline
\end{tabular}

World stock indices:

\begin{tabular}{lll}
\hline country & symbol & name \\
\hline China & $\wedge$ 000001.SS & SSE Composite index \\
France & $\wedge$ FCHI & CAC40 \\
Germany & $\wedge$ GDAXI & DAX PERFORMANCE INDEX \\
Hong Kong & $\wedge$ HSI & HANG SENG INDEX \\
Japan & $\wedge$ N225 & Nikkei225 \\
United Kingdom & $\wedge$ FTSE & FTSE100 \\
US & $\wedge$ GSPC & S\&P500 \\
US & $\wedge$ DJI & DOW 30 \\
\hline
\end{tabular}




\section{REFERENCES}

1. Armansyah R. F.; Effendi M. B., (2017). Modeling the financial crisis in Indonesia. Ventura-J. Econ. Bus. Acc., 20(2): 125-132 (8 pages). URL: https://journal.perbanas.ac.id/index.php/jebav/article/view/1127/pdf

2. Basu K., (2009). A Simple Model of the Financial Crisis of 2007-9 with Implications for the Design of a Stimulus Package. CAE Working Pap., No. 09-11, Cornell Univ., Cent. Anal. Econ. (CAE), Ithaca, NY (23 pages). URL: https:// basu.economics.cornell.edu/docs/09-11.pdf

3. Bocola L.; Bornstein G.; Dovis A., (2019). Quantitative sovereign default models and the European debt crisis. J. Int. Econ., 118: 20-30 (11 pages). URL: https://www.sciencedirect.com/science/article/pii/S0022199618302848

4. Burnside C.; Eichenbaum M.; Rebelo S., (2007). Currency crises models (8 pages). URL: https://www.kellogg.northwestern.edu/faculty/rebelo/htm/currency \%20crisis\%20models\%20Ed.pdf

5. Chen X.; Hao A.; Li Y., (2020). The impact of financial contagion on real economy-An empirical research based on combination of complex network technology and spatial econometrics model. PloS one, 15(3), e0229913. URL:https://doi.org/10.1371/journal.pone.0229913

6. Colander D.; Föllmer H.; Haas A.; Goldberg M.; Juselius K.; Kirman A.; Lux T.; Sloth B., (2009). The Financial Crisis and the Systemic Failure of Academic Economics. Univ. Copenhagen Dept. Econ. Discussion Pap., No. 09-03 (18 pages). DOI: $10.1080 / 08913810902934109$

$7 . \quad$ Danylchuk, H.; Derbentsev, V.; Soloviev, V.; Sharapov, A., (2016). Entropy analysis of dynamic properties of regional stock markets. Sci. Educ. New Dimension Econ., IV (2): 15-19 (5 pages). URL:https:/ / www.slideshare.net/SocietyforCulturalan/science-and-education-a-new-dimension-economics-issue-94

8. Danylchuk H.; Kibalnyk L.; Kovtun O.; Kiv A.; Pursky O.; Berezhna G., (2020). Modelling of cryptocurrency market using fractal and entropy analysis in COVID-19. Proc. Selected Pap. Spec. Edition Int. Conference Monitoring, Model. Manage. Emergent Econ. (M3E2-MLPEED 2020), pp. 352-371 (20 pages). URL: http://ceur-ws.org/Vol-2713/paper40.pdf

9. Danylchuk H.; Kibalnyk L.; Serdiuk O., (2019). Study of critical phenomena in economic systems using a model of damped oscillations. SHS Web Conf., Vol. 65: 06008, EDP Sciences (8 pages). URL: https://doi.org/10.1051/shsconf/20196506008

10. Gertler M.; Kiyotaki N.; Prestipino A., (2017). A Macroeconomic Model with Financial Panics (63 pages). URL:https:/ / doi.org/10.17016/IFDP.2017.1219

DOI: $10.2307 / 20798381$ Harvey J., (2010). Modeling financial crises: A schematic approach. J. Post Keynesian Econ., 33(1): $61-82$ (31 pages).

12. InvestFunds - stock quotes online, (2021). Verizon Media. Accessed 4 Apr 2021. URL: http:/ investfunds.ua

13. Mariano R. S.; Gultekin B. N.; Ozmucur S.; Shabbir T., (2000). Models of Economic and Financial Crises. Top. Middle Eastern and Afr. Econ., Vol. URL:https:/ / meea.sites.luc.edu/volume2/PDFS/Models\%20of\%20Economic\%20and\%20Financial.pdf

14. Perez D.G.; Zunino L.; Garavaglia M.; Rosso O.A., (2005). Wavelet entropy and fractional Brownian motion time series. arXiv:physics/0501105 v1 19 Jan 2005 (10 pages). URL: https://cds.cern.ch/record/816320/files/0501105.pdf

15. Quiroga R. Q.; Rosso O.A.; Başar E., (1999). Wavelet entropy: a measure of order in evoked potentials. Electroencephalogr. Clin. Neurophysiol. Suppl., 49: 299-303 (5 pages). URL: https://www.researchgate.net/profile/Osvaldo-Rosso3/publication/12767753_Wavelet_entropy_a_measure_of_order_in_evoked_potentials/links/590344e74585152d2e92c0d0/Wavelet -entropy-a-measure-of-order-in-evoked-potentials.pdf

16. Soloviev V.; Belinskiy A., (2018). Methods of nonlinear dynamics and the construction of cryptocurrency crisis phenomena precursors. arXiv preprint arXiv:1807.05837 (12 pages). URL: http://ceur-ws.org/Vol-2104/paper_175.pdf

17. Soloviev V.; Saptsin V., (2011). Heisenberg uncertainty principle and economic analogues of basic physical quantities. arXiv preprint arXiv:1111.5289 (21 pages) URL: https://arxiv.org/pdf/1111.5289.pdf

18. Soloviev V.; Serdiuk O.; Semerikov S.; Kohut-Ferens O., (2019). Recurrence entropy and financial crashes. 7th Int. Conference Model., Dev. Strategic Manage. Econ. Syst. (MDSMES 2019), pp. 385-388, Atlantis Press (4 pages). URL: https://doi.org/10.2991/mdsmes-19.2019.73

19. Strutt A.; Walmsley T., (2011). Implications of the global financial crisis for China: A dynamic CGE analysis to 2020. Econ. Res. Int. (9 pages). URL: https:/ / www.hindawi.com/journals/ecri/2011/926484/

20. Wieland V.; Wolters M., (2012). Macroeconomic model comparisons and forecast competitions/ URL: https://voxeu.org/article/failed-forecasts-and-financial-crisis-how-resurrect-economic-modelling

21. Yahoo Finance - Business Finance, Stock Market, Quotes, News, (2021). Verizon Media. Accessed 4 Apr 2021. URL: https:/ / finance.yahoo.com

22. Zunino L.; Perez D.G.; Garavaglia M.; Rosso O.A., (2006). Wavelet entropy of stochastic processes, arXiv:physics/0603144 v1 17 Mar 2006 (12 pages). URL: https://cds.cern.ch/record/936162/files/0603144.pdf 


\title{
МОДЕЛЮВАННЯ КРИЗОВИХ ЯВИЩ НА РЕГІОНАЛЬНИХ ФОНДОВИХ РИНКАХ МЕТОДОМ ВЕЙВЛЕТ-ЕНТРОПІї
}

\author{
ГАННА ДАНИЛЬЧУК, ЛЮБОВ КІБАЛЬНИК
}

Черкаський національний університет імені Богдана Хмельницького

У статті знайшли відображення результати дослідження з моделювання регіональних фондових ринків із використанням вейвлет-ентропії. Особлива увага приділяється періодам особливих станів ринків - кризовим явищам. Для дослідження було обрано країни із розвиненими економіками: Сполучені Штати Америки, Велика Британія, Німеччина, Франція, Китай, Японія та Гонг Конг. В якості статистичної бази використано значення біржових індексів регіональних фондових ринків. Період дослідження - з 2015 по 2021 рр. Метою статті є моніторинг поточного стану ринків та демонстрація можливостей використання показника вейвлет-ентропї в якості індикатора-передвісника кризових явищ.

Використано метод вейвлет-ентропї. Всі розрахунки проведено у середовищі Манlав - системі для моделювання нелінійних динамічних систем.

Результати дослідження демонструють відсутність кризових явищ на иих ринках станом на квітень 2021 року. Показано що використання вейвлет-ентропії в якості індикатора-передвісника є обтрунтованим. Зокрема, показано реакцію фондових ринків на такі кризові ситуації як пандемія COVID-19, а також на інші соціально-політичні події.

За результатами розрахунків зроблено висновки щодо сучасного стану фондових ринків досліджуваних крайн. Отримані результати, як і Використання вказаного методу, можуть бути використані всіма учасниками фондових ринків, інвесторами, а також відповідним міністерствами для розробки ефективних стратегій.

Кеушотds: економічні кризи; моделювання; регіональні фондові ринки; Вейвлет ентропія; індикатор-передвісник. 